\section{Andrzej Kubanowski}

Uniwersytet Mikołaja Kopernika w Toruniu

Wydział Teologiczny

e-mail: a.kubanowski@gmail.com

DOI: http://dx.doi.org/10.12775/BPTh.2015.017

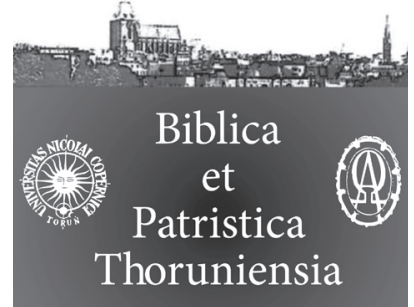

$8(2015) 3$

ISSN (print) 1689-5150

ISSN (online) 2450-7059

\title{
W poszukiwaniu sensów Pisma Świętego. Św. Tomasza z Akwinu Super Epitolam ad Ephesios i wybrane nowożytne interpretacje egzegetyczne na przykładzie Ef 5,1-2*
}

\author{
In Searching of Senses of Holy Scripture. \\ St. Thomas Aquinas' Super Epistolam ad Ephesios \\ and selected modern exegetical interpretations \\ of Eph. 5:1-2
}

Streszczenie. Celem tego artykułu jest porównanie komentarza Akwinaty do fragment Ef 5,1-2 z nowożytnymi komentarzami biblijnymi i odpowiedź na pytanie dotyczące hermeneutycznych ścieżek prowadzących do zrozumienia sensów Pisma Świętego. Na samym początku autor przedstawia główne kierunki odnowy współczesnej egzegezy. Następnie ogólnie opisuje hermeneutyczne narzędzia stosowane przez Tomasza z Akwinu. Po obszernym wprowadzeniu autor artykułu rozpoczyna właściwą egzegezę fragmentu Ef 5,1-2. Bazując na Super Epistolam ad Ephesios lectura, przedstawia interpretację Akwinaty do kolejnych wersetów listu i porównuje je ze współczesnymi komentarzami takich autorów, jak: M. Barth, E. Best, F.F. Bruce, A. Jankowski, H. Langkammer i R. Schnackenburg. Wyciągnięte z tego wnioski okazują się pozytywne i dające nadzieje na kontynuowanie poszukiwań wspólnego języka hermeneutyki pomiędzy średniowieczną egzegezą a nowożytnymi interpretacjami biblijnymi.

Abstract. The purpose of this paper is comparison Aquinas's commentary to Eph. 5:1-2 with modern exegetical commentaries and answer to question about true hermeneutical ways to understanding biblical senses. In the beginning, author presents the main directions to renew a contemporary exegesis. Next, he describe a general hermeneutical tools used by Aquinas. After this comprehensive introduction author begins an exact exegesis. Based on Super Epistolam ad Ephesios lectura he features Aqui-

Artykuł przygotowany na podstawie referatu o tym samym tytule, wygłoszonego na konferencji: „The Biblical Exegesis of Thomas Aquinas and its Contemporary Relevance”, 21.04.2015 r., w Toruniu. 
nas's interpretation of the next biblical verses and compares them with contemporary interpretations from M. Barth, E. Best, F.F. Bruce, A. Jankowski, H. Langkammer and R. Schnackenburg. The conclusions are positive and hopeful for the continuous researches of mutual hermeneutical language between medieval exegesis and modern biblical interpretations.

Słowa kluczowe: Tomasz z Akwinu; List do Efezjan; egzegeza Biblii; egzegeza kanoniczna; odnowa egzegezy; narzędzia hermeneutyczne.

Keywords: Thomas Aquinas; Epistle to the Ephesians; exegesis of Bible; canonical execesis; exegesis renew; hermeneutical tools.

Renedykt XVI podczas swojego pontyfikatu był gorącym orędownikiem B powrotu do kanonicznej lektury Pisma Świętego. Wyraz temu dał nie tylko w adhortacji Verbum Domini oraz książce Jezus z Nazaretu, lecz również w wielu publikacjach i wystąpieniach. Jednak jeszcze wcześniejszym sygnałem dla ponownego zwrócenia się ku egzegezie, która towarzyszyła Kościołowi już od samych jego początków była konstytucja Vaticanum II - Dei Verbum. Ojcowie soborowi dostrzegli niewystarczalność historyczno-krytycznej metody w odczytywaniu Pisma Świętego, dlatego pragnęli zaproponować coś, co byłoby zgodne z duchem samej Biblii. Dlatego też, tak szczególną uwagę zwrócili na postulat, aby Pismo Święte było odczytywane w tym samym duchu, w którym zostało napisane (KO 12). Kwestia ducha, pisanego raz wielką, raz małą literą, ściśle wiąże się z kwestią natchnienia, a tym samym również żywą tradycją Kościoła, której Pismo stanowi konieczny element i najważniejszy przekaźnik. Nie dziwi więc fakt, że szeroko pojęta egzegeza kanoniczna, która winna być

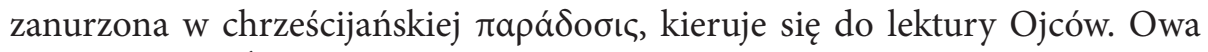
lektura Pisma Świętego prowadzona przez Ojców nie zamyka się wyłącznie w okresie patrystycznym, lecz przechodzi także do średniowiecznej egzegezy, która pomimo pewnego rysu spekulatywnego czerpie z niej pełnymi garściami. Znamienitym tego potwierdzeniem jest egzegetyczna spuścizna św. Tomasza z Akwinu. Doctor angelicus w swoim nauczaniu był bardzo silnie osadzony na lekturze Ojców. Rzucającym się w oczy wyrazem tego jest chociażby Catena Aurea do Czterech Ewangelii zawierająca kompilacje komentarzy wczesnochrześcijańskich autorytetów do konkretnych wersetów Nowego Testamentu ${ }^{1}$.

1 Zob. J. Weisheipl, Tomasz z Akwinu. Życie, myśl i dzieło, 225-228: Jak podaje sam autor za innymi badaczami, Tomasz z Akwinu wykazywał się sporą dbałością o przekłady pism Ojców greckich, dlatego też zlecał pewne korekty ówcześnie znanym tłumaczom, prawdopodobnie również Wilhelmowi z Moerbeke. Co interesujące, nie jest prawdą jakoby 
Lecz ten związek z Ojcami i pisarzami Kościoła jest również widoczny w jego własnych komentarzach do poszczególnych ksiąg Pisma Świętego. Nie będziemy tu jednak zajmować się szczegółową deskrypcją tych odniesień. Skierujmy się raczej do jednego z elementów Tomaszowej metody egzegetycznej, który w szczególny sposób implikuje w sobie ten cały charakter kanonicznej lektury Pisma Świętego. Elementem tym jest koncept auctoritas i wykorzystanie go nie tylko jako pewnego twierdzenia, lecz przede wszystkim gwaranta prawdziwości, w którym pokładana jest odpowiedzialność za prawdę². Dlatego też autorytet w metodzie Akwinaty jest trójstopniowy. Najwyższy stopień posiada auctoritas Divina, czyli sam Bóg. Jest On źródłem prawdy, ostatecznym jej weryfikatorem, a także przyczyną tego, że prawda prowadzi człowieka ku dobru³. Drugi stopień znajduje się w auctoritas Sacrae Scripturae. W myśl zasady locum ex loco jeden fragment Pisma Świętego można wyjaśnić za pomocą innego fragmentu. Przy czym kolejno przywoływane biblijne passusy nie są li tylko serią kategorycznych argumentów potwierdzających ostateczny charakter konkretnej interpretacji. Akwinata cytaty przywołujące auctoritas Sacrae Scripture traktuje także jako drogowskazy kierujące człowieka drogami prowadzącymi do poszczególnych sensów Pisma Świętego ${ }^{4}$. Trzeci stopień posiada auctoritas docendi, w którym umieszczeni zostają również Ojcowie i pisarze Kościoła. Jednak sam św. Tomasz w Sumie teologicznej zwraca uwagę, że autorytet Ojców jest całkowicie zależy od autorytetu Kościoła ${ }^{5}$. Ojcowie są przekazicielami Kościelnej Tradycji, która żyje w ich nauczaniu i to ona właśnie stanowi źródło dla ich autorytetu. Inaczej ujmując, Ojcowie i pisarze wczesnochrześcijańscy posiadają auctoritas ze względu na to, że trwali w prawdziwej Tradycji Kościo$\mathfrak{~ ł a}^{6}$. Dlatego uzasadniona wydaje się teza, że komentarz do Pisma Świętego, który spoczywa na wewnętrznym autorytecie samego Pisma oraz Ojcach Kościoła trwających w jego Tradycji jest bliższy autentycznemu sensowi Biblii, w przeciwieństwie do komentarza egzegetycznego całkowicie oderwanego od chrze-

Akwinata bazował wyłącznie na Ojcach łacińskich. Między innymi w Catena Aurea liczba poczynionych przez niego odniesień do greckich autorów wczesnochrześcijańskich jest znacznie większa niż do autorów z kręgu łacińskiego.

2 P. Roszak, Autorytet a poszukiwanie mądrości. Wokół konceptu auctoritas $w$ teologii św. Tomasza z Akwinu, 73.

3 Ibidem, 77-78.

4 P. Roszak, The Place and Function of Biblical Citations in Thomas Aquinas's Exegesis, 119-124.

5 S.Th., II-II, q. 10, a. 12c.

6 M. Mróz, P. Roszak, Tomasza z Akwinu ideał egzegety i podstawy jego pracy in Sacra Pagina, 120. 


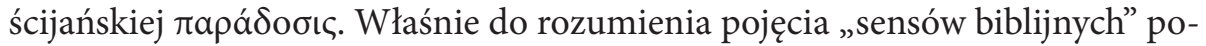
winniśmy się jeszcze odnieść.

Tomasz z Akwinu w swojej metodzie egzegetycznej skupia się przede wszystkim wokół sensu literalnego, który można nazwać również sensem dosłownym, bądź też historycznym. Jego zasadę stanowi znaczenie konkretnych słów (voces), lecz nie wyosobnionych $\mathrm{z}$ tekstu, ale uwzględniających ich kontekst i formy retoryczne (np. metafora jest odczytywana jako metafora, a parabola jako parabola). Z sensu dosłownego wynika i na nim jest osadzony sens duchowy, którego zasadę stanowią rzeczywistości (res) i wydarzenia opisywane za pomocą konkretnych słów. Akwinata sensus spiritualis dzieli jeszcze na trzy kategorie: sens alegoryczny, synonimy: typiczny, mistyczny oraz figuratywny; sens moralny oraz sens anagogiczny, w którym opisywane rzeczywistości odnoszą się do kategorii eschatologicznych. Bardziej szczegółowy opis tego podziału znajduje się w Summa theologiae, I, q. 1, a. 10 oraz w Super Epistolam B. Pauli ad Galatas lectura, c. 4, 1. 7 7 . Jak sama nazwa wskazuje w sensie duchowym istotną rolę odgrywa „Duch” i to nie jakiś nieokreślony „duch”, ale Ten, który tchnie, czyli Duch Święty ${ }^{8}$. Natchnienie bowiem nie ogranicza się wyłącznie do procesu redakcyjnego samej litery Pisma, lecz jest także koniecznym elementem jego odczytania, a następnie przepowiadania. Stąd też lektura duchowa przebiega według określonych kryteriów: 1) sens duchowy zawsze wywodzi się z sensu literalnego; 2) lektura duchowa winna być zawsze dokonywana w środowisku, w którym powstało Pismo Święte, czyli ortodoksyjnej Tradycji Kościoła; 3) z zachowaniem reguły analogia fidei, komplementarności wszystkich sensów biblijnych oraz jedności obydwu Testamentów; 4) przy udziale Łaski Ducha Świętego ${ }^{9}$. W związku z czwartym kryterium, rozumienie duchowe Pisma Świętego ma także charakter indywidualny, ponieważ rzeczywistość łaski jest autonomiczna i dynamizująca, zdolna przekraczać wszelkie nasze rozumienie ${ }^{10}$.

7 S.Th., I, q. 1, a. 10c.; Super Epistolam ad Galatas, c.4, 1.7; Quod. VII, q. 6, a. 14-15; H. De Lubac, Pismo Święte w Tradycji Kościoła, 30-31; P. Roszak, Between Dialectics and Metaphor. Dynamics of Exegetical Practice of Thomas Aquinas, 514-515; W. Świerzawski, Egzegeza biblijna i teologia spekulatywna św. Tomasza z Akwinu, 36-37.

8 H. de Lubac, Pismo Święte, 33.

9 S. Haręzga, En Pneumati jako zasada interpretacji Pisma św. we wschodniej tradycji Kościoła, passim. Zob. M. Gołębiewski, Jedność Pisma Świętego jako zasada hermeneutyczna, 5-17.

10 Zob. H. De Lubac, Pismo Święte, 37-38: „Tym samym, rozumienie takie [duchowe] nie może prowadzić do skutków, które można byłoby w pełni kontrolować, stosując jakąkolwiek metodę, i które można by ująć w jakiś ostateczny kanon. Zarazem więc, nie może ono nigdy zupełnie się zobiektywizować”. Natomiast: „(...) znaczenie duchowe nie jest ani oso- 
W świetle przedstawionych twierdzeń pytanie o prawdziwość poszczególnych sensów biblijnych jawi się jako pytanie źle postawione. Sens biblijny bowiem zawsze jest prawdziwy, tylko jego odczytanie może być autentyczne, mniej autentyczne lub zafałszowane. Na przykładzie komentarza Akwinaty do dwóch wersetów z Listu do Efezjan postaramy się odnaleźć to bogactwo sensów nowotestamentalnej epistoły i spojrzeć na nie w perspektywie tych ścieżek hermeneutycznych oraz kryteriów autentyczności, o których zostało wspomniane wcześniej. Następnie przyjrzymy się interpretacjom późniejszym (Markusa Bartha, Rudolfa Schnackenburga, Ernesta Besta, Frederika F. Bruce’a, Hugolina Langkammera i Augustyna Jankowskiego), aby sprawdzić w zestawieniu $\mathrm{z}$ fragmentem Super Epistolam ad Ephesios, czy posiadają one jakiekolwiek wspólne odniesienia. Pojawia się jednakże problem różnicy metodologicznej, który dla niektórych stanowi nieprzekraczalną barierę w zestawianiu ze sobą dawnych i nowszych interpretacji. Jednak dla przykładu, jeżeli mierzymy temperaturę $\mathrm{w}$ tym samym pomieszczeniu za pomocą różnych termometrów (np. rtęciowego, alkoholowego, elektronicznego), które przedstawiają pomiar w różnych skalach (np. $\left.{ }^{\circ} \mathrm{C}, \mathrm{K},{ }^{\circ} \mathrm{F}\right)$, to przecież cały czas badamy tę samą rzeczywistość. Dlatego jeśli uzyskane rezultaty uzgodnimy w ramach jednego układu odniesienia, to wyniki pomiarów okażą się stosunkowo zbieżne. Podobnie więc powinno być w przypadku biblijnej egzegezy. W związku z powyższym, czy aby na pewno między Akwinatą a nowożytnymi egzegetami istnieje hermeneutyczna przepaść, która jest nie do przekroczenia? Czy może istnienie różnorodności odczytań biblijnego tekstu jest jedynie złudzeniem wynikającym z osobistej postawy odczytującego, np. jego denominacji. Spróbujemy się temu przyjrzeć odnosząc się do komentarzy Ef 5,1-2 ${ }^{11}$.

Tomasz z Akwinu na samym początku swojego komentarza umieszcza podział (divisio textus). Wersety 1 i 2 stanowią u niego oddzielne lectio. Pozostali autorzy albo umieszczają ten fragment $\mathrm{w}$ ramach większej sekcji od 4,25 do 5,2, albo od 5,1 do 5,20 (M. Barth). Jedynie H. Langkammer i F. Bruce dodatkowo wyodrębniają te dwa wersety. Dla Akwinaty Ef 5,1-2 jest formą exemplum do wcześniejszej ekshoratcji, jaką Efezjanom przedstawia Apostoł Paweł. Pozostali autorzy owo upomnienie dostrzegają również tutaj. Dla Toma-

bistą, ani prywatną interpretacją (...). Innymi słowy, znaczenie duchowe jest prawdziwym i obiektywnym sensem zamierzonym przez Ducha Świętego (...)”, cyt. za: J. A. Weisheipl, Tomasz z Akwinu, 145.

11 Tekst Ef 5,1-2 odtworzony na podstawie komentarza Akwinaty: ${ }^{1)}$ Ergo estote imitatores Dei sicut fili carissimi, ${ }^{2)}$ et ambulate in dilectione sicut et Christus dilexit nos et tradidit semetipsum pro nobis in oblationem et hostiam Deo in odorem suavitatis. 
sza z Akwinu w. 1 stanowi zachętę do naśladowania (imitatio) samego Boga ${ }^{12}$. W. 2 bardziej szczegółowo pokazuje, co w Bogu chrześcijanie powinni naśladować, dalej dookreślając, że chodzi o postępowanie miłości, której znakiem było wydanie się Chrystusa ${ }^{13}$.

Naśladowanie samego Boga wiąże się z tematem postawy darowania bliźnim za ich występki z Ef 4,32. „Bycie naśladowcami Boga” jest więc dla chrześcijan najwyższą powinnością. W nawiązaniu do Ef 5,1 cytat z Koh 2,12, który św. Tomasz przywołuje w swoim komentarzu, podkreśla, że człowiek nie jest w stanie uczynić czegokolwiek ponad to, co uczynił dla niego sam Bóg. Dlatego też postawa odzwierciedlająca Boże działanie jest konieczna do osiągnięcia przez człowieka doskonałości własnej natury. Jednak, co podkreśla Akwinata, to „samowydoskonalenie” nie jest możliwe bez ścisłej łączności z Bogiem. Stąd powołanie się na przykład z Hi 23,11 o kroczeniu po Bożych śladach ${ }^{14}$. M. Barth prawdopodobnie $\mathrm{z}$ tego zaczerpnął inspiracje do metafory ojca tworzącego dla dziecka ślady w głębokim śniegu, którą wykorzystał w swoim komentarzu do opisu konceptu imitacji Boga ${ }^{15}$. Wracając jednak do myśli Tomasza z Akwinu. Człowiek winien naśladować Boga w najwyższym stopniu na jaki pozwala mu na to jego własna natura, ponieważ jest synem Bożym, a w ramach starożytnej zasady moralnej dzieci powinny naśladować swojego ojca. Przy tym Akwinata podkreśla, że Bóg jest Ojcem ludzi ze względu na akt stwórczy ${ }^{16}$. Określenie umiłowania zaznacza fakt szczególnego wybrania (elegit ${ }^{17}$ ) chrześcijan do udziału w rzeczywistości samego Boga. M. Barth sugeruje, że kluczem według którego Tomasz z Akwinu rozumie imitatio Dei jest koncepcja pochodząca ze Starego Testamentu oraz Ewangelii o podążaniu za Bogiem (podążać za Chrystusem, por. 1 P 2,21; 1 Tes 1,6; 1 Kor 11,1). Samo zaś naśladowanie Boga jest tym samym, co naśladowanie Chrystusa, czyli życiem według przykazania mi-

12 Thomae Aquinatis, Super Epistolam B. Pauli ad Ephesios lectura, c. 5, 1. 1, nr 266 [dalej jako: In Eph.].

13 Ibidem, nr 268.

14 Ibidem, nr 267.

15 M. Barth, Ephesians, Translation and Commentary on Chapters 4-6, 554-555.

16 Zob. A. Kubanowski, Nam grater est, et quantum ad generationem gratiae...- Analiza chrystianologiczna Listu do Filemona w świetle Super Epistolam B. Pauli ad Philemonem lectura św. Tomasza $z$ Akwinu, 88: Przy temacie braterstwa Tomasz z Akwinu odnosi się również do Bożego Ojcostwa, które w przypadku chrześcijan jest dwojakie. Po pierwsze dotyczy ono faktu stworzenia, przez co posiada charakter pierwotny i uniwersalny wobec wszystkich ludzi. Po drugie dotyczy ono faktu zrodzenia w łasce, przez co posiada charakter wtórny i ekskluzywny dotyczący obecnych chrześcijan, a potencjalnie każdego człowieka.

17 elego, -are,-avi: zapisać coś testamentem komuś spoza rodziny, za: Słownik łacińsko-polski, D-H, t. 2, M. Plezia (red.), 304. 
łości ${ }^{18}$. Odnośnie wersetu 1. autorzy pozostałych komentarzy podkreślają, że termin „naśladowcy Boga” występuje tu jedyny raz w całej Biblii. Większość z nich upatruje źródła tego konceptu w judaistycznym temacie kroczenia narodu wybranego za Jahwe (Księga Kapłańska) dodając do niego również wpływy helleńskiego naśladownictwa figury bóstwa. Wg E. Besta istotą owego naśladowania jest miłość do bliźnich objawiająca się w przebaczaniu im, co nawiązywałoby by również do idei naśladowania życia Chrystusa. Nie chodzi jednak o ścisłe powtarzanie czynów historycznego Jezusa, lecz bardziej o etyczną perspektywę miłości Boga, jako przebaczenia ${ }^{19}$. Nie akcentuje on jednak ontycznej relacji, na którą wskazuje określenie „umiłowani synowie Boga”. Podobnie F. Bruce, który skupiając się na naśladownictwie Boga wymienia trzy możliwości rozumienia tej idei. Pierwsza dotyczy naśladowania Boga w przebaczeniu, jak dzieci naśladujące ojca. Druga naśladowania Chrystusa, tak jak to czynili uczniowie. Trzecia naśladowania Pawła przez członków wspólnot, które ewangelizowa ${ }^{20}$. Natomiast H. Langkammer, A. Jankowski i R. Schackenburg podobnie do św. Tomasza, choć oczywiście innymi wyrażeniami, kładą naciska na nadprzyrodzony wymiar relacji, która zachodzi między Bogiem a chrześcijaninem stającym się synem umiłowanym. Apostolskie orędzie ma również rodzić we wspólnocie jeszcze większą obligację do postępowania godnego nowego stanu ontycznego, który jest zapoczątkowywany w chrzcie. Naśladowanie Boga nie jest wyłącznie jakimś mimetyzmem postawy przebaczenia, lecz głęboką relacją miłości, w której chrześcijanin jest obdarowywany przez Ducha. Celem tegoż jest uświęcenie ${ }^{21}$.

Za św. Tomaszem z Akwinu przejdźmy do omówienia wersetu 2. Na początku dokonuje on ponownie divisio textus, gdzie pierwsza część wersetu odnosi się do sposobu naśladowania Boga w miłości, druga natomiast, od słów „i wydał”, przedstawia największy znak owej Bożej miłości ${ }^{22}$. W nawiązaniu do koncepcji naśladowania ojca przez dzieci chrześcijanie muszą być naśladowcami Boga (auctoritas Sacre Scripture za: Rz 8,15; Rdz 17,1) i nieustannie czynić postępy w miłości. Postawa miłości jest bowiem najlepszą dla człowieka, ponieważ ze swej istoty domaga się ona ciągłego doskonalenia (proficere) oraz

18 M. Barth, Ephesians, 555-556.

19 E. Best, A Critical and Exegetical Commentary on Ephesians, 465-466.

20 F.F. Bruce, The Epistles to the Colossians, to Philemon and to the Ephesians, 363.

21 H.Langkammer, Komentarz teologiczno-pastoralny wszystkich listów św. Pawła Apostoła z okazji roku Świętego Pawła. Listy Więzienne św. Pawła, 87-88; A. Jankowski, Listy Więzienne Świętego Pawła, 465-466; R. Schnackenburg, Ephesians, A Commentary, 210.

${ }^{22}$ In Eph., nr 268. 
odwzajemnienia (semper solvere ${ }^{23}$ ). Przez to stanowi również idealną postawę w relacjach z innymi ludźmi. Przybliża człowieka do Boga, co św. Tomasz potwierdza cytatami z 1 Kor 12,31 i 1 Kor 13,124. Natomiast M. Barth, E. Best, a poniekąd też A. Jankowski w początkowym przynagleniu Apostoła „i postępujcie w miłości jak Chrystus" dostrzegają potwierdzenie tego, że koncept naśladowania Boga z w. 1 odpowiada ewangelicznej idei podążania za Chrystusem. To podążanie jednak nie ma wymiaru soteriologicznego, lecz raczej etyczno-obidiencyjny oparty na posłuszeństwie Woli Bożej i jakby całkowite „zatracenie się" w miłości do Boga i bliźnich ${ }^{25}$. Najdoskonalszym przykładem tej postawy miłości jest wydarzenie Jezusa Chrystusa, który „... umiłowawszy swoich, którzy byli na świecie, do końca ich umiłował" (J 13,1) ${ }^{26}$. Akwinata, powołując się na zdanie Grzegorza Wielkiego z jego homilii do Ewangelii według św. Jana (przykład auctoritas docendi), zwraca uwagę na fakt, że dowodami miłości są zawsze jej dzieła. Dlatego też Apostoł Paweł mówił o naśladowaniu Chrystusa, jako tego, który wydał siebie samego za ludzi, co Tomasz z Akwinu pointuje cytatami z Ap 1,5; Ga 2,20 i Iz 53,1227. Według pozostałych autorów chrześcijańska miłość jest zawsze ukierunkowane ku Chrystusowi. To miłość Chrystusa do ludzi stanowi najważniejszą motywację oraz porównanie dla własnych działań (E. Best). Jest fundamentem i jedyną miarą podług której człowiek może spoglądać na miłość będącą jego udziałem (R. Schnackenburg ${ }^{28}$. Jednakże H. Langkammer dodaje, że Chrystusowy wzór zawiera w sobie również postulat ontycznej zmiany chrześcijanina, którą sygnalizował także św. Tomasz. Perspektywa dziecięctwa Bożego czerpiącego z dzieła Jezusa Chrystusa dopiero, gdy jest utwierdzona na podstawie ontycznej zyskuje odbicie w moralności. Egzystencja chrześcijańska, tak jak u Chrystusa, przekształca się w proegzystencje ${ }^{29}$. Stąd też Akwinata mówi o konieczności śmierci Chrystusa na krzyżu, jak również o korzyści jaka z tego wypłynęła dla

23 Słowo to posiada bardzo wiele znaczeń, które nawiązują do „uwolnienia”, „rozwikłania”, „zakończenia czegoś, „darowania”, „odpłaty”, „wypełnienia zobowiązania”, a nawet „poniesienia kary”. Można przypuszczać, że użycie przez Akwinatę wieloznacznego solvo, -ere w kontekście miłości było nieprzypadkowe i miało wskazywać na różnorodność aspektów zawierających się w jej obrębie.

24 In Eph., nr 269.

25 M. Barth, Ephesians, 555; E. Best, A Critical, 467; A. Jankowski, Listy Więzienne, 466.

26 In Eph., nr 269: Odnośnik biblijne również przywołane za św. Tomaszem z Akwinu.

27 Ibidem, nr 270.

28 E. Best, A Critical, 467; F.F. Bruce, The Epistles, 364; R. Schnackenburg, Ephesians, 211.

29 H. Langkammer, Komentarz teologiczno-pastoralny, 88. 
ludzi ${ }^{30}$. Według prawa zawartego w Kpł 4,25 ten, który zgrzeszył był zobowiązany złożyć za siebie ofiarę przebłagalną oraz wyznaczony dar. Także w przypadku składania dziękczynienia, czy prośby prawo o ofierze i darze obowiązywało. Kpł 3,9-16 potwierdza, że dary dziękczynne były najbardziej przyjemne Bogu. Chrystus więc „wydał siebie samego za nas w darze”, którym jest Jego ziemskie życie, Jego nauka, Jego Kościół oraz Jego sakramenty, a także „ofierze" za ludzkie grzechy. Całkowicie wypełnił więc starotestamentalne prawo ${ }^{31}$. F. Bruce interesująco stwierdza, że Chrystusowa ofiara i dar stanowią nawiązanie do wspólnego aktu Ojca i Syna w ramach jednego ordo salutis ${ }^{32}$. M. Barth natomiast, odnośnie tego fragmentu czyni rozważania dotyczące chrystologicznego wymiaru ofiary i daru, jako elementów krwawej i bezkrwawej ofiary. Według niego chrześcijanie mogą swoim życiem partycypować w darze Chrystusa, lecz przez wzgląd na szczególność Chrystusowej ofiary krzyża nie mogą jej powtarzać, ani naśladować ${ }^{33}$.

Ostatnia część w. 2 zawiera zwrot "na zapach przyjemny” (in odorem suavitatis), który Tomasz z Akwinu również wywodzi z tradycji kapłańskiej (Kpł 3,5). Jego wyjaśnienie jest jednak dość enigmatyczne. Podstawę dla niego stanowią dwa cytaty z Rdz 27,27: „oto woń syna mego, jako woń pełnego pola” oraz Pnp 1,3: „pociągnij mnie za sobą biegnijmy w woni twoich maści” ${ }^{34}$. Według Akwinaty ów „zapach przyjemny” nie jest przyjemny Bogu ze względu na swoje materialne źródło, tzn. czy pochodzi od kwiatów, czy wonnych kadzideł. Jest on przyjemny o ile symbolizuje woń z daru ciała Chrystusa, Syna Bożego. Dlatego ludzie także mogą składać Bogu duchowe dary (Ps 51,19), z których największym jest Eucharystia ${ }^{35}$. W pewien sposób nawiązuje do tego E. Best, który zwrot „zapach przyjemny” w kontekście ofiary Chrystusa interpretuje w wymiarze soteriologiczny. Samą symbolikę jednak traktuje dosyć dosłownie i rozpatruje ją w perspektywie judaistycznych rytuałów ${ }^{36}$. Pozostali autorzy dostrzegają tu szczególne wyróżnienie doskonałej ofiary Chrystusa, w której

30 Zob. S.Th., III, q. 47, a. 3; a. 4, ad 2.

31 In Eph., nr 270.

32 F.F. Bruce, The Epistles, 364.

33 K. Barth, Ephesians, 557.

34 Tekst oryginalny za In Eph., nr 270: ecce odor filii mei, sicut odor agri pleni (Rdz 27,27); trahe me post te, curremus in odorem unguentorum tuorum (Pnp 1,3).

35 In Eph., nr 270. Przez takie rozwiązanie kwestii „przyjemnego zapachu” św. Tomasz wskazuje na prawdziwe znaczenie wszystkich wonnych ofiar składanych według starotestamentalnych zasad.

36 E. Best, A Critical, 469. 
przez duchową i osobową więź z ludźmi cała ludzkość oddaje się Ojcu w posłuszeństwie miłości ${ }^{37}$.

Podsumowując, Tomasz z Akwinu w wybranym fragmencie komentarza do Listu do Efezjan prezentuje niemal wszystkie właściwości stosowanej przez siebie metody egzegetycznej. Trzyma się sensu literalnego, ale na jego kanwie nakreśla również sens alegoryczny i moralny. Bardzo intensywnie korzysta $\mathrm{z}$ autorytetu samego Pisma Świętego i przywołuje fragmenty, które jego zdaniem same przez siebie tłumaczą istotę zagadnienia. Raz także powołuje się na zdanie św. Grzegorza Wielkiego. Podjęty przez nas fragment nie ukazuje jeszcze całego bogactwa Tomaszowej egzegezy. W przyszłości wskazana byłaby obszerniejsza analiza. Jak jednak na tle średniowiecznej egzegezy Akwinaty wypadają pozostałe komentarze? Odnośnie tego krótkiego fragmentu można stwierdzić, że ta hermeneutyczna przepaść nie jest wcale tak olbrzymia. Owszem autorzy nowożytni wprowadzają w swoich komentarzach do Ef 5,1-2 elementy właściwe metodzie historyczno-krytyczniej, określoną teologię o konkretnym zabarwieniu konfesyjnym oraz różne koncepcje chrystologiczne i moralne. Różnią się także stylem prowadzonej narracji. Jednak w perspektywie wybranego fragmentu nie są niezgodni $\mathrm{z}$ wywodem św. Tomasza. Można także powiedzieć, że czerpią z jego myśli, jak i metody pewne inspiracje (np. M. Barth, E. Best i A. Jankowski bezpośrednio przywołują zdanie Akwinaty). Kilkukrotnie również powołują się na te same biblijne fragmenty wyjaśniające lub te same starotestamentalne tradycje (np. tradycja z Księgi Kapłańskiej odnośnie ofiary). W niektórych momentach komentarze bardziej współczesnych egzegetów kreatywnie uzupełniają myśl św. Tomasza. Dlatego słuszny wydaje się postulat, aby we współczesnej interpretacji Pisma Świętego wykorzystywać i twórczo łączyć ze sobą podejście Tomasza z Akwinu oraz nowożytnych badaczy. Czasami, gdy jest to wskazane, podejmować pewną polemikę lub krytykę. Patrząc na powyższe zadanie, nie wydaje się niemożliwe to do zrealizowania. Największy problem tkwi jednak w dobrym zrozumieniu komentarzy Akwinaty. Do tego potrzebna jest bowiem całościowa znajomość jego myśli i średniowiecznych koncepcji, z których korzystał. Stąd też zaawansowane studia nad Tomaszową egzegezą biblijną wydają się niezbędne dla poszerzenia horyzontu współczesnej egzegezy, która pragnie na nowo stawać się egzegezą kanoniczną Kościoła.

37 K. Barth, Ephesians, 558; F.F. Bruce, The Epistles, 364; H. Langkammer, Komentarz teologiczno-pastoralny, 88; A. Jankowski, Listy Więzienne, 467. W rozwinięciu interpretacji zwrotu z Ef 5,2b może pomóc zestawienie go z fragmentem Flp 4,18, w którym również się pojawia, zob. E. Jezierska, Dobry czyn człowieka - „wdzięczną wonnością” Bogu, Refleksje w oparciu o Ef 5,2 i Flp 4,18, 21-25. 


\section{Bibliografia}

\section{Źródła:}

S. Thomae Aquinatis, Super Epistolas S. Pauli lectura, t. 1, Super Epistolam B. Pauli ad Galatas lectura, ed. R. Cai, $8^{\text {a }}$ ed., Marietti, Taurini-Romae 1953.

S. Thomae Aquinatis, Super Epistolas S. Pauli lectura, t.2, Super Epistolam B. Pauli ad Ephesios lectura, ed. R. Cai, $8^{\text {a }}$ ed., Marietti, Taurini-Romae 1953.

Sancti Thomae Aquinatis, Opera omnia iussu Leonis XIII P.M. edita, t. 25/1, Préface. Quaestiones de quolibet. Quodlibet VII, VIII, IX, X, XI, Roma-Paris 1996.

Sancti Thomae Aquinatis, Opera omnia iussu Leonis XIII P.M. edita, t. 4-12, Summa theologiae, Roma 1888-1906.

\section{Opracowania i komentarze:}

Barth M., Ephesians, Translation and Commentary on Chapters 4-6, The Anchor Yale Bible, vol. 34A, New York 1974.

Best E., A Critical and Exegetical Commentary on Ephesians, ICC, Edinburgh 1998.

Bruce F.F., The Epistles to the Colossians, to Philemon and to the Ephesians, NICNT. Grand Rapids 1984.

De Lubac H., Pismo Święte w Tradycji Kościoła, tłum. K. Łukowicz, Kraków 2008.

Gołębiewski M., Jedność Pisma Świętego jako zasada hermeneutyczna, „Collectanea Theologica" 53/1 (1983), s. 5-17.

Haręzga S., En Pneumati jako zasada interpretacji Pisma św. we wschodniej tradycji Kościoła, „Ruch Biblijny i Liturgiczny” 43 (1990), s. 111-121.

Jankowski A., Listy Więzienne Świętego Pawła, KUL, t. 8, Poznań 1962.

Jezierska E.J., Dobry czyn człowieka - „wdzięczna wonnościa” Bogu, Refleksje w oparciu o Ef 5,2 i Flp 4,18, „Poznańskie Studia Teologiczne” 4(1986), s. 21-25.

Kubanowski, Nam grater est, et quantum ad generationem gratiae...- Analiza chrystianologiczna Listu do Filemona $w$ świetle Super Epistolam B. Pauli ad Philemonem lectura św. Tomasza z Akwinu, „Biblica et Patristica Thoruniensia” 8/1 (2015), s. 81-97.

Langkammer H., Komentarz teologiczno-pastoralny wszystkich listów św. Pawła Apostoła z okazji roku Świętego Pawła. Listy Więzienne św. Pawła, t. 2, Legnica 2010.

Mróz M., Roszak P., Tomasza z Akwinu ideat egzegety i podstawy jego pracy in Sacra Pagina, “Teologia i Człowiek” 10 (2007), s. 113-130.

Plezia M. (red.), Słownik łacińsko-polski, D-H, t. 2, Warszawa 1998.

Roszak P., Autorytet a poszukiwanie mądrości. Wokół konceptu auctoritas $w$ teologii św. Tomasza z Akwinu, „Człowiek w Kulturze” 22 (2011/2012), s. 67-90.

Roszak P., Between Dialectics and Metaphor. Dynamics of Exegetical Practice of Thomas Aquinas, „Angelicum” 90 (2013), s. 507-534. 
Roszak P., The Place and Function of Biblical Citations in Thomas Aquinas's Exegesis, w: Reading Sacred Scripture with Thomas Aquinas. Hermeneutical Tools, Theological Questions and New Perspectives, R. Roszak, J. Vijgen (red.), Turnhout 2015, 115-139.

Schnackenburg R., Ephesians, A Commentary, trans. H. Heron, Edinburgh 1991.

Świerzawski W., Egzegeza biblijna i teologia spekulatywna św. Tomasza z Akwinu, „Znak” 22/187 (1970), s. 27-41.

Weisheipl J., Tomasz z Akwinu. Życie, myśl i dzieło, tłum. Cz. Wesołowski, Poznań 1985. 